\title{
Cadmium and lead concentrations in Moniliformis moniliformis (Acanthocephala) and Rodentolepis microstoma (Cestoda), and in their definitive hosts, Rattus rattus and Mus domesticus in El Hierro (Canary Archipelago, Spain)
}

\author{
Jordi Torres ${ }^{1,2^{\star}}$, Catarina Eira ${ }^{3}$, Jordi Miquel ${ }^{1,2}$, Pilar Foronda ${ }^{4}$ and Carlos Feliu ${ }^{1,2}$ \\ ${ }^{1}$ Departament de Microbiologia i Parasitologia Sanitàries, Facultat de Farmàcia, Universitat de Barcelona (UB), Av. Joan XXIII s/n, \\ 08028 Barcelona, Spain. ${ }^{2}$ Institut de Recerca de la Biodiversitat, Universitat de Barcelona, Av. Diagonal, 645, 08028 Barcelona, Spain. \\ ${ }^{3}$ CESAM and Department of Biology, University of Aveiro, 3810-193 Aveiro, Portugal. ${ }^{4}$ Department of Parasitology, \\ Ecology and Genetics, Pharmacy Faculty, University of La Laguna, C/Astrofísico F. Sánchez sn, 38206 La Laguna (Tenerife), Spain
}

\begin{abstract}
Information on parasites of vertebrates living in terrestrial ecosystems as monitoring tools for heavy metal environmental pollution is scarce. The present study evaluates the potential suitability of the models Rattus rattus/Moniliformis moniliformis and Mus domesticus/Rodentolepis microstoma as promising bioindicator systems for cadmium and lead pollutions under natural conditions. The highest level of cadmium was found in one specimen of M. moniliformis (335.2 $\mathrm{ng} \mathrm{g}^{-1}$ wet weight) and the average concentration of $\mathrm{Cd}$ in the acanthocephalan was significantly higher than values found in $R$. rattus liver and kidney tissues. The maximum concentration of lead occurred in one specimen of $R$. microstoma (567.4 $\mathrm{ng} \mathrm{g}^{-1}$ wet weight) and the average concentration of $\mathrm{Pb}$ in the cestode was significantly higher than values found in $M$. domesticus liver, kidney and muscle tissues. The present results allow proposing both models as promising biomonitoring systems to evaluate environmental cadmium pollution (mainly R. rattus/M. moniliformis) and lead contamination (especially M. domesticus/R. microstoma) in terrestrial nonurban habitats.
\end{abstract}

\section{Keywords}

Heavy metals, Moniliformis moniliformis, Rodentolepis microstoma, biomonitoring system, environmental pollution, Canary Archipelago

\section{Introduction}

Heavy metals are widespread in the environment and can be responsible for toxic effects in the biota. The use of rodents to evaluate these effects is limited despite their proven relevancy to predict environmental risk (Alleva et al. 2006, Hamers et al. 2006, Sánchez-Chardi et al. 2007). Using small mammals for biomonitoring is useful for the assessment of environmental quality, especially in areas of high ecological interest such as El Hierro Island (Canary Archipelago).

Apart from the use of small mammals when inferring about the presence of toxic elements in certain habitats, recent studies evidenced that some helminth parasites are able to accumulate much more heavy metals than their hosts in various environments. However, most of the helminth/host systems tested for this purpose (involving fish, birds or mammals) have been examined in freshwater habitats (e.g. Sures 2004, 2008; Vidal-Martínez et al. 2010). Therefore, the available information about systems involving rodents and some of their helminth parasites is scarce. In fact, few experimental (Scheef et al. 2000; Sures et al. 2000a, 2002) and field studies (Sures et al. 2003; Torres et al. 2004, 2006) have been performed using cestode and acanthocephalan parasites of rodents. This general lack of information motivates the need for further studies on organisms or models that may reflect small-scale differences in heavy metal pollution in terrestrial ecosystems.

In non-synanthropic areas of El Hierro Island, Rattus rattus and Mus domesticus are the only existing rodent species, which are often infected by Moniliformis moniliformis and Rodentolepis microstoma, respectively. The aim of the present study is to evaluate the potential suitability of both host- 
parasite systems (R. rattus/M. moniliformis and M. domesticus $/$ R. microstoma) as promising bioindicators for cadmium and lead pollution under natural field conditions. In addition, this study allowed inferring about the degree of environmental quality in this emblematic island of the Canary Archipelago.

\section{Materials and methods}

El Hierro $\left(27^{\circ} 44^{\prime} \mathrm{N}, 18^{\circ} 33^{\prime} \mathrm{W}\right)$, the smallest island of the Canary Archipelago, Spain, was declared a Biosphere Reserve by UNESCO in 2000. It has a surface of $268 \mathrm{~km}^{2}$. Rodents were collected using Sherman traps in several areas of the island during 2008 and 2009. After rodents have been scanned for helminths, 14 Rattus rattus parasitised by M. moniliformis (collected in the "Lagartario" area) and 10 Mus domesticus parasitised by $R$. microstoma (collected in the "Fayal-Brezal" area) were selected for cadmium and lead analysis.

The "Lagartario" capture site $\left(27^{\circ} 46^{\prime} \mathrm{N}, 17^{\circ} 59^{\prime} \mathrm{W}\right.$ and only 76 meters a.s.1.) is close to the main road in the island connecting Valverde (the capital of the island) and the village of Frontera. The "Fayal-Brezal" capture site $\left(27^{\circ} 44^{\prime} \mathrm{N}, 17^{\circ} 59^{\prime} \mathrm{W}\right)$ is located far away of any village in the highest part of the island (1305 meters a.s.1.).

Samples of kidney, liver and muscle of each rodent as well as adult specimens of M. moniliformis and gravid R. microstoma were taken using stainless-steel instruments. All samples were frozen at $-20^{\circ} \mathrm{C}$ until being processed for metal analysis. Around $50-150 \mathrm{mg}$ (wet weight) of the above mentioned samples were mineralized in Teflon vessels using $2 \mathrm{ml}$ $\mathrm{HNO}_{3}$ (Merck, Suprapur) and $1 \mathrm{ml} \mathrm{H} \mathrm{O}_{2}$ (Panreac) and left overnight in an oven at $90^{\circ} \mathrm{C}$. The whole process was standardized and validated in the (detection limits and accuracy of results) as described in detail in Torres et al. (2004). All concentrations were presented as $\mathrm{ng} \mathrm{g}^{-1}$ wet weight. Bioaccumulation factors (BF) in helminths were calculated as proposed by Sures et al. (1999).

\section{Results}

Mean cadmium and lead concentrations in tissues of analysed rodents and their helminths are shown in Table I. The detection limits (mean blank value plus three standard deviations of the mean blank) for both elements were lower than $1 \mathrm{ng} \mathrm{ml}^{-1}$ and accuracy values were greater than $95 \%$.

The highest level of cadmium was found in one specimen of M. moniliformis (335.2 $\mathrm{ng} \mathrm{g}^{-1}$ wet weight). The maximum concentration of lead occurred in one specimen of R. microstoma (567.4 $\mathrm{ng} \mathrm{g}^{-1}$ wet weight). Similarly, the highest average concentration of cadmium was found in M. moniliformis (95.6 $\mathrm{ng} \mathrm{g}^{-1}$ ), whereas the highest average concentration of lead was found in R. microstoma (241.3 $\left.\mathrm{ng} \mathrm{g}^{-1}\right)$.

There were significant differences in $\mathrm{Cd}$ average concentrations among $R$. rattus tissues and also between hosts' tissues and the acanthocephalan M. moniliformis (KruskalWallis, $\mathrm{H}=39.77, \mathrm{P}<0.001)$. In fact, the cadmium average concentration is lower in $R$. rattus muscle when comparing to both liver and kidney tissue (Dunn's test, $\mathrm{P}<0.05$ and $\mathrm{P}<0.001$, respectively) and its average concentration in the acanthocephalan is higher than in $R$. rattus liver and muscle tissue (Dunn's test, $\mathrm{P}<0.01$ and $\mathrm{P}<0.001$, respectively). With respect to $M$. domesticus, there were also significant differences in cadmium average concentrations among the analysed tissues when comparing host and R. microstoma (Kruskal-Wallis test, $\mathrm{H}=27.04, \mathrm{P}<0.001$ ). Both $R$. microstoma and kidney tissue presented higher average cadmium concentrations than muscle tissue (Dunn's test, both $\mathrm{P}<0.001$ ). When comparing the analysed helminths, the average cadmium concentrations in $M$. moniliformis (parasitising $R$. rattus) was higher than in R. microstoma (parasitising M. domesticus) (Mann-Whitney test, $\mathrm{U}=30.00, \mathrm{P}=0.02$ ).

With respect to lead, there were significant differences in average concentrations among $R$. rattus tissues and also when comparing host tissues to M. moniliformis (Kruskal-Wallis, $\mathrm{H}$ $=42.78, \mathrm{P}<0.001)$. In fact, considering the hosts' tissues, the lead average concentration is higher in kidneys when comparing to both liver and muscle tissue (Dunn's test, $\mathrm{P}<0.01$

Table I. Concentrations of cadmium and lead in tissues of $R$. rattus and M. domesticus and in M. moniliformis and $R$. microstoma (ng g ${ }^{-1}$ wet weight; mean $\pm \mathrm{SE}$ ). $\mathrm{BF}=$ bioaccumulation factors

\begin{tabular}{|c|c|c|c|c|c|}
\hline & & R. rattus & BF & M. domesticus & BF \\
\hline Cd & $\begin{array}{l}\text { Kidney } \\
\text { Liver } \\
\text { Muscle } \\
\text { M. moniliformis } \\
\text { R. microstoma }\end{array}$ & $\begin{aligned} 77.8 & \pm 23.9 \\
14.7 & \pm 3.0 \\
1.1 & \pm 0.2 \\
95.6 & \pm 21.9\end{aligned}$ & $\begin{array}{r}1.2 \\
6.5 \\
86.9\end{array}$ & $\begin{array}{c}41.5 \pm 10.1 \\
12.5 \pm 0.9 \\
0.8 \pm 0.2 \\
48.5 \pm 14.6\end{array}$ & $\begin{array}{c}1.2 \\
3.9 \\
60.6\end{array}$ \\
\hline $\mathbf{P b}$ & $\begin{array}{l}\text { Kidney } \\
\text { Liver } \\
\text { Muscle } \\
\text { M. moniliformis } \\
\text { R. microstoma }\end{array}$ & $\begin{aligned} 87.4 & \pm 14.7 \\
22.5 & \pm 2.2 \\
12.6 & \pm 1.8 \\
141.6 & \pm 27.7\end{aligned}$ & $\begin{array}{r}1.6 \\
6.3 \\
11.2\end{array}$ & $\begin{aligned} 9.2 & \pm 0.9 \\
13.3 & \pm 2.0 \\
8.6 & \pm 0.6 \\
241.3 & \pm 51.6\end{aligned}$ & $\begin{array}{l}26.2 \\
18.1 \\
28.1\end{array}$ \\
\hline
\end{tabular}


and $\mathrm{P}<0.001$, respectively). Also, the lead average concentration in M. moniliformis is higher than in the liver and muscle tissue of $R$. rattus (Dunn's test, $\mathrm{P}<0.001$ and $\mathrm{P}<0.001$, respectively). The most interesting results refer to the significant differences detected among the lead average concentrations in $M$. domesticus tissues and $R$. microstoma (KruskalWallis, $\mathrm{H}=24.51, \mathrm{P}<0.0001$ ). In fact, the lead average concentration in R. microstoma was higher than in M. domesticus liver, kidney and muscle tissue (Dunn's test, $\mathrm{P}<0.05, \mathrm{P}<0.001$ and $\mathrm{P}<0.001$, respectively). When comparing the average lead concentrations detected in hosts' tissues, kidney and liver presented higher values in $R$. rattus than in M. domesticus (MannWhitney test, $\mathrm{U}=00.00, \mathrm{P}<0.001$ and $\mathrm{U}=25.00, \mathrm{P}=0.0092$, respectively).

The highest bioaccumulation factor $(\mathrm{BF})$ was obtained for cadmium (Table I) considering that the average concentration of $\mathrm{Cd}$ in M. moniliformis was 86.9-times higher than that in $R$. rattus muscle. The average concentration of $\mathrm{Cd}$ in $R$. $m i$ crostoma was also 60.6-times higher than that in M. domesticus muscle. The average concentration of lead in M. moniliformis was 11.2-times higher when compared to muscle of $R$. rattus. On the other hand, the average lead concentration in R. microstoma was 18 to 28 -times higher than in tissues of M. domesticus (Table I).

\section{Discussion}

Most studies aiming at assessing environmental quality have focused on areas, which were at least expected to be polluted such as floodplains, landfills, dumping sites, mine areas, or where accidents have occurred (Grimalt et al. 1999, Hamers et al. 2006, Pereira et al. 2006, Torres et al. 2006, SánchezChardi et al. 2007). Contrarily, insufficient attention is paid to areas of high ecological importance that may also be subject to several types of lower or indirect anthropogenic chemical stress. The environmental quality of protected areas is often high because they are usually subjected to low disturbance. However, it should be taken into account that long-term pollutant activities may disturb some ecosystems making them less suitable for wildlife.

An earlier study using the model Apodemus sylvaticus/Gallegoides arfaai (Torres et al. 2004) under natural field conditions in NE continental Spain revealed much higher $\mathrm{Cd}$ concentrations in kidneys (644.9 $\mathrm{ng} \mathrm{g}^{-1}$ wet weight) than those found in either of the hosts evaluated in El Hierro. Another earlier study using the model A. sylvaticus/Skrjabinotaenia lobata (Torres et al. 2006) in the urban dumping site of Garraf (located only $32 \mathrm{~km}$ away from Barcelona city) reported $\mathrm{Pb}$ levels only slightly higher (144.8 and $15.1 \mathrm{ng} \mathrm{g}^{-1}$ w.w. in kidney and muscle, respectively) than those evidenced in El Hierro but the reported Cd concentrations were again much higher (959.2 and $9.5 \mathrm{ng} \mathrm{g}^{-1}$ w.w. in the same tissues) than those detected in the present survey (Table I).
Other studies on small mammals from contaminated sites including A. sylvaticus from a landfill in NE Spain (SánchezChardi et al. 2007) and $R$. rattus and M. spretus from an abandoned mine area in SE Portugal (Pereira et al. 2006) revealed higher amounts of $\mathrm{Pb}$ and $\mathrm{Cd}$ than levels found in the evaluated rodents collected in El Hierro. Therefore, it is evident that contamination levels in El Hierro are much lower than those reported in other areas of the Iberian Peninsula (Spain and Portugal). However, when comparing the areas included in the present study, there were significantly higher $\mathrm{Pb}$ concentrations in liver and kidney of $R$. rattus collected in "El Lagartario" than in M. domesticus collected in "FayalBrezal". Apart from the possible effect of interspecific variability (which cannot be confirmed considering the available data) the observed differences should be a result of anthropogenic contamination in "El Lagartario" area where human pressure is higher, including the presence of motor vehicles. These results confirm that the environmental quality of zones that have partial or complete protection status is often high. However, long-term pollutant activities might disturb some ecosystems that require a systematic control using suitable species or helminthological models as biomonitors of pollution by heavy metals.

The study on A. sylvaticus/G. arfaai (Torres et al. 2004) constituted the first evaluation of $\mathrm{Cd}$ bioaccumulation using a terrestrial host-cestode system. However, the authors concluded that this system was not efficient in monitoring environmental Cd pollutions. Since then, other terrestrial vertebrate/cestode models have been evaluated such as Oryctolagus cuniculus/Mosgovoyia ctenoides (Eira et al. 2005), Skrjabinotaenia lobatalApodemus sylvaticus (Torres et al. 2006) and Raillietina micracantha/Columba livia (Torres et al. 2010). However, they were all found to be unsuccessful as promising bioindicator systems of environmental $\mathrm{Cd}$ pollution, much like the model $M$. domesticus/R. microstoma evaluated in the present study.

With respect to acanthocephalan parasites of mammals, few terrestrial models for the evaluation of $\mathrm{Cd}$ bioaccumulation are available. A study involving specimens of Macracanthorhynchus hirudinaceus infecting pigs revealed 32-times and 5-times more $\mathrm{Cd}$ in the acanthocephalan than in their hosts' liver and kidney, respectively (Sures et al.2000a). Also, the system including $M$. moniliformis and experimentally infected rats had already been demonstrated as a highly sensitive bioindicator in terrestrial and urban ecosystems (Scheef et al. 2000). The same system was evaluated in the present study under natural conditions and bioaccumulation factors with respect to liver and muscle seem to corroborate its usefulness for the evaluation of $\mathrm{Cd}$, although values obtained by Scheef et al. (2000) in their experimental study were much more significant.

As for the evaluation of $\mathrm{Pb}$ bioaccumulation using acanthocephalans parasites of mammals in terrestrial habitats, two systems involving Macracanthorhynchus hirudinaceus and Moniliformis moniliformis have been evaluated (Sures et al. Brought to you by | Universidade de Aveiro 
2000a, b). In our study, the bioaccumulation factors obtained for $R$. rattus/M. moniliformis are in line with those obtained experimentally by Sures et al. (2000b), thus supporting the suitability of this system as a useful and promising tool in environmental monitoring.

Also considering the terrestrial compartment, the system Rattus norvegicus/Hymenolepis diminuta was the first host/cestode system to be evaluated for its possible capacity of $\mathrm{Pb}$ accumulation both under experimental conditions (Sures et al. 2002) and in the field (Sures et al. 2003). The latter was performed in the city of Cairo (Egypt) and the evaluated host-parasite model was confirmed as a promising bioindicator system for $\mathrm{Pb}$ in urban ecosystems (Sures et al. 2003). Other subsequent field studies included cestode parasites of rodents (Apodemus sylvaticus; Torres et al. 2004, 2006), lagomorphs (Oryctolagus cuniculus; Eira et al. 2005) and terrestrial urban birds (Columba livia; Torres et al. 2010). The BFs obtained in the present study seem to confirm that cestodes with a relatively large tegumental surface in respect to their weight should reach high bioaccumulation factors and therefore they could be theoretically considered good biomonitoring tools as postulated by Torres et al. (2006). Also, cestodes efficiently collect bile salts, which have formed organometallic complexes with metal ions, becoming available in the intestine through the hepatic intestinal cycle (Sures and Siddall 1999). It is possible that this capacity for collecting bile salts is enhanced in R. microstoma because it is usually found in the liver (inside the bile ducts) and duodenum. In fact the BFs reported in our study for this cestode are quite high (Table I) considering the scarcely polluted sampling area.

Considering the presently available data, it can be concluded that the widely distributed rodents $R$. rattus and $M$. domesticus are suitable biomonitoring species of environmental pollution by heavy metals. This has been confirmed by the lower contamination expected in El Hierro in comparison to several unprotected areas in the Iberian Peninsula. However, even though El Hierro is a very small island, the anthropogenic pollution was emphasised in the Lagartario area, which presented $\mathrm{Pb}$ contamination levels similar to continental Spanish areas. In addition, the present data also allow proposing both models as promising biomonitoring systems to evaluate environmental $\mathrm{Cd}$ pollution (R. rattus/M. moniliformis) and $\mathrm{Pb}$ pollution (mainly $M$. domesticus/R. microstoma) in terrestrial non-urban habitats. In fact, due to its hepatic and duodenal sites of infection and its small size, $R$. microstoma can be considered a good indicator for environmental $\mathrm{Pb}$ pollution in non-urban terrestrial habitats.

Acknowledgements. This study was supported by the Spanish projects CLG2009-07759/BOS and 2009-SGR-403. Authors wish to thank all personnel for their contribution to the development of this study. The methods used in this study comply with the current Spanish laws.

\section{References}

Alleva E., Francia N., Pandolfi M., De Marinis A.M., Chiarotti F., Santucci D. 2006. Organochlorine and heavy-metal contaminants in wild mammals and birds of Urbino-Pesaro Province, Italy: an analytic overview for potential bioindicators. Archives of Environmental Contamination and Toxicology, 51, 123-134. DOI: 10.1007/s00244-005-0218-1.

Eira C., Torres J., Vingada J., Miquel J. 2005. Concentration of some toxic elements in Oryctolagus cuniculus and in its intestinal cestode Mosgovoyia ctenoides, in Dunas de Mira (Portugal). Science of the Total Environment, 346, 81-86. DOI: 10.1016/ j.scitotenv.2004.11.014.

Grimalt J., Ferrer M., Macpherson E. 1999. The mine tailing accident in Aznalcollar. Science of the Total Environment, 242, 3 11. DOI: 10.1016/S0048-9697(99)00372-1.

Hamers T., van den Berg J.H.J., van Gestel C.A.M., van Schooten F.J., Murk A.J. 2006. Risk assessment of metals and organic pollutants for herbivorous and carnivorous small mammal food chains in a polluted floodplain (Biesbosch, The Netherlands). Environmental Pollution, 144, 581-595. DOI: 10.1016/ j.envpol.2006.01.020.

Pereira R., Pereira M.L., Ribeiro R., Gonçalves F. 2006. Tissues and hair residues and histopathology in wild rats (Rattus rattus L.) and Algerian mice (Mus spretus Lataste) from an abandoned mine area (Southeast Portugal). Environmental Pollution, 139, 561-575. DOI: 10.1016/j.envpol.2005.04.038.

Sánchez-Chardi A., Peñarroja-Matutano C., Oliveira C.A., Nadal J. 2007. Bioaccumulation of metals and effects of a landfill in small mammals. Part II. The wood mouse, Apodemus sylvaticus. Chemosphere, 70, 101-109. DOI: 10.1016/j.chemosphere.2007.06.047.

Scheef G., Sures B., Taraschewski H. 2000. Cadmium accumulation in Moniliformis moniliformis (Acanthocephala) from experimentally infected rats. Parasitology Research, 86, 688-691.

Sures B. 2004. Environmental parasitology: Relevance of parasites in monitoring environmental pollution. Trends in Parasitology, 20, 170-177. DOI: 10.1016/j.pt.2004.01.014.

Sures B. 2008. Environmental parasitology. Interactions between parasites and pollutants in the aquatic environment. Parasite, 15, 434-438.

Sures B., Siddall R. 1999. Pomphorhynchus laevis: The intestinal acanthocephalan as a lead sink for its fish host, chub (Leuciscus cephalus). Experimental Parasitology, 93, 66-72. DOI: 10.1006/expr.1999.4437.

Sures B., Siddall R., Taraschewski H. 1999. Parasites as accumulation indicators of heavy metal pollution. Parasitology Today, 15, 16-21. DOI: 10.1016/S0169-4758(98)01358-1.

Sures B., Franken M., Taraschewski H. 2000a. Element concentrations in the archiacanthocephalan Macracanthorhynchus hirudinaceus compared with those in the porcine host from a slaughterhouse in La Paz, Bolivia. International Journal for Parasitology, 30, 1071-1076. DOI: 10.1016/S0020-7519(00) 00094-1.

Sures B., Jürgues G., Taraschewski H. 2000b. Accumulation and distribution of lead in the archiacanthocephalan Moniliformis moniliformis from experimentally infected rats. Parasitology, 121, 427-433. DOI: 10.1017/S0031182099006 $54 \mathrm{X}$.

Sures B., Grube K., Taraschewski H. 2002. Experimental studies on the lead accumulation in the cestode Hymenolepis diminuta and its final host, Rattus norvegicus. Ecotoxicology, 11, 365368. DOI: 10.1023/A:1020561406624.

Sures B., Scheible T., Bashtar A.R., Taraschewski H. 2003. Lead concentrations in Hymenolepis diminuta adults and Taenia tae- 
niaeformis larvae compared to their rat host (Rattus norvegicus) sampled from the city of Cairo, Egypt. Parasitology, 127, 483-487. DOI: 10.1017/S00311822003003901.

Torres J., de Lapuente J., Eira C., Nadal J. 2004. Cadmium and lead concentrations in Gallegoides arfaai (Cestoda: Anoplocephalidae) and Apodemus sylvaticus (Rodentia: Muridae) from Spain. Parasitology Research, 94, 468-470. DOI: 10.1007/s00436-004-1232-3.

Torres J., Foronda P., Eira C., Miquel J., Feliu C. 2010. Trace element concentrations in Raillietina micracantha in comparison to its definitive host, the feral pigeon Columba livia in Santa Cruz de Tenerife (Canary Archipelago, Spain). Archives of Environmental Contamination and Toxicology, 58, 176182. DOI: 10.1007/s00244-009-9352-5.
Torres J., Peig J., Eira C., Borrás M. 2006. Cadmium and lead concentrations in Skrjabinotaenia lobata (Cestoda: Catenotaeniidae) and in its host, Apodemus sylvaticus (Rodentia: Muridae) in the urban dumping site of Garraf(Spain). Environmental Pollution, 143, 1-5. DOI: 10.1016/j.envpol.2005.11.012.

Vidal-Martínez V.M., Pech D., Sures B., Purucker S.T., Poulin R. 2010. Can parasites really reveal environmental impact? Trends in Parasitology, 26, 44-51. DOI: 10.1016/j.pt.2009.11.001.

(Accepted April 26, 2011) 